\title{
Penerimaan Pendapatan Pajak Daerah di Daerah Kabupaten/Kota se Daerah Istimewa Yogyakarta 1997-2015
} Achmad Lutfi ${ }^{1}$

${ }^{1}$ Universitas Indonesia, Kota Depok, Provinsi Jawa Barat

\section{ARTICLE INFO \\ JEL Classification: \\ H21, H71}

Key words:

Local Tax, Fiscal Decentralization, open

list system, closed list system, Intergovernmental Fiscal Relations

\begin{abstract}
This article aims to explain the implementation of tax decentralization in Indonesia, in particular the study of the implementation of open list systems and closed list systems in the local tax collection of districts and municipality in the Daerah Istimewa Yogyakarta. In implementing tax decentralization, the Government of Indonesia implements an open list system and a closed list system in the collection of local taxes by autonomous regions. The research was conducted using qualitative strategy and enriched with quantitative analysis. More in-depth investigations conducted in districts and municipality in Daerah Istimewa Yogyakarta indicate that the implementation of this policy has not been able to reduce the income gap in local revenues derived from the components of local taxes received by districts and municipality. To reduce the revenue gap in local revenues from local taxes collected by district and municipality governments, it is necessary to transfer local taxation power on the basis of potential local taxes to district and municipality governments. The local tax base to be proposed must be owned by each local government.
\end{abstract}

\begin{abstract}
ABSTRAK
Artikel ini bertujuan untuk menjelaskan pelaksanaan desentralisasi perpajakan di Indonesia, khususnya kajian tentang penerapan sistem daftar terbuka dan sistem daftar tertutup pada pemungutan pajak daerah kabupaten dan kota di Daerah Istimewa Yogyakarta. Dalam melaksanakan desentralisasi perpajakan, Pemerintah Indonesia menerapkan sistem daftar terbuka dan sistem daftar tertutup dalam pemungutan pajak daerah oleh daerah otonom. Penelitian dilakukan dengan menggunakan strategi kualitatif dan diperkaya dengan analisis kuantitatif. Investigasi lebih mendalam yang dilakukan di kabupaten dan kota di Daerah Istimewa Yogyakarta menunjukkan bahwa penerapan kebijakan ini belum mampu mengurangi kesenjangan pendapatan dalam pendapatan asli daerah yang bersumber dari komponen pajak daerah yang diterima kabupaten dan kota. Untuk mengurangi kesenjangan penerimaan penerimaan daerah dari pajak daerah yang dipungut oleh pemerintah kabupaten dan kota, maka diperlukan penyerahan kewenangan perpajakan daerah berdasarkan potensi pajak daerah kepada pemerintah kabupaten dan kota. Basis pajak daerah yang akan diusulkan harus dimiliki oleh masingmasing pemerintah daerah.
\end{abstract}

\section{PENDAHULUAN}

Desentralisasi fiskal yang dilakukan oleh pemerintah pusat kepada pemerintah daerah ini dapat dilihat dari dua sisi (Lutfi, 2013a : 1). Pertama, desentralisasi fiskal di sisi penerimaan, yaitu pemberian kemampuan keuangan bagi pemerintah daerah untuk menggali potensi pendapatan di daerahnya sendiri yang mewujud pada pendapatan asli daerah dan memperoleh alokasi keuangan dari tingkatan pemerintahan yang lebih tinggi.
Kedua, desentralisasi fiskal di sisi pengeluaran, yaitu pemberian kewenangan kepada daerah untuk melakukan pengeluaran, melakukan pembelanjaan, untuk membiayai tugas-tugas umum pemerintahan yang diembannya serta tugas-tugas pembangunan yang dimilikinya.

Dari serangkaian pembahasan mengenai sumber-sumber pendapatan yang dimiliki oleh pemerintah daerah di Indonesia, dapat dipastikan bahwa sumber-sumber pendapatan yang dimiliki ini telah sesuai dengan kelaziman 
yang ada. Sumber-sumber pendapatan yang dimiliki daerah ini pun sejalan dengan pandangan yang dikemukakan oleh para teoritisi, seperti Tanzi (1985), Rondinelli (2000), Devas (2008), serta Campo-McFerson (2008), sebagaimana tertulis dalam literaturliteraturnya. Lazimnya sumber-sumber pendapatan daerah yang dimiliki oleh pemerintah-pemerintah daerah dibelahan dunia lainnya, sumber-sumber pendapatan daerah di Indonesia dapat diklasifikasikan dalam dua golongan besar, yaitu berasal dari alokasi keuangan antar tingkat pemerintahan dan pendapatan yang diusahakan sendiri oleh daerah berkat pemberian kewenangan yang diberikan oleh tingkatan pemerintahan yang lebih tinggi, atau di Indonesia dikenal dengan konsep Pendapatan Ali Daerah (PAD).

Penelitian dalam rangka penulisan artikel ini dilakukan dengan strategi kualitatif dan diperkaya dengan analisis kuantitatif. Strategi kualitatif digunakan untuk memahami bagaimana pengaturan yang dilakukan oleh pemerintah dalam mengimplementasikan kebijakan desentralisasi pemungutan pajak daerah yang tertuang dalam serangkaian peraturan perundang-undangan sebagai bentuk regulasi yang dibuat oleh pemerintah pemerintah pusat. Untuk memperkaya analisis terhadap regulasi yang dilakukan oleh pemerintah pusat dalam pengatur pemungtan pajak daerah, analisis diperkaya dengan melakukan analisis data deskriptif atas data penerimaan pajak daerah yang diterima oleh pemerintah kabupaten dan pemerintah kota dalam periode 1997 - 2015 dan jenis-jenis penerimaan lainnya yang diperoleh pemerintah kabupaten dan pemerintah kota dalam periode yang sama. Untuk lebih memberikan gambaran yang lebih jelas, secara lebih mendalam, penulisan ini menggambarkan pemungutan pajak daerah oleh pemerintah daerah kabupaten dan pemerintah daerah kota di Daerah Istimewa Yogyakarta pada periode 1997 - 2015 untuk memperoleh gambaran yang lebih jelas atas fenomena yang sama di tingkat lokal.

Pemilihan Daerah Istimewa Yogyakarta sebagai lokasi studi didasari oleh pemikiran bahwa di dalam satu wilayah provinsi ini secara sekaligus terdapat daerah kabupaten dan kota yang memiliki perkembangan menarik, baik dari sisi perkembangan daerah perkotaannya maupun dari sisi perkembangan daerah pedesaannya. Daerah perdesaan yang mengalami perkembangan dan perubahan diwakili oleh Daerah Kabupaten Bantul, Daerah Kabupaten Gunung Kidul, dan Daerah Kabupaten Kulon Progo. Ketiga daerah kabupaten ini sangat menarik dilihat perubahannya dari sisi daerah pedesaan dan perkembangan sektor pertanian dan sektor ekonomi non pariwisatanya. Daerah Perkotaan diwakili oleh Daerah Kota Yogyakarta, wilayah perkotaan yang berkembang pesat dan ditopang dengan sektor ekonomi berbasis jasa dan pariwisata yang kuat. Daerah yang unik adalah Kabupaten Sleman, daerah kabupaten yang mengalami perkembangan akibat urbanisasi dan perekonomian yang ditopang sektor pertanian, sektor jasa. dan sektor pariwisata

Pemilihan kurun waktu 1997-2015 dilakukan dalam rangka melihat perubahan yang dimunculkan akibat diberlakunya tiga undang-undang yang mengatur perpajakan daerah, yaitu UU 18/1997, UU 34/2000 dan 28/2009. Undang-Undang Nomor 18 Tahun 1997 tentang Pajak Daerah dan Retribusi Daerah diberlakukan dalam kurun waktu 19972000. Undang-Undang Nomor 34 tahun 2000 tentang Pengganti Undang-Undang Nomor 18 Tahun 1997 tentang Pajak Daerah dan Retribusi Daerah diberlakukan dalam kurun waktu 20002009. Undang-Undang Nomor 34 Tahun 2009 merupakan undang-undang perpajakan daerah yang menggantikan UU 34/2000. Rentang waktu yang tidak terlalu panjang dan relatif saling terkait ini dipandang dapat menghasilkan data yang valid dan memberikan gambaran jika terjadi perubahan atau tidak terjadi perubahan akibat perubahan pemberlakuan undang-undang yang mengatur tentang pemungutan pajak tersebut.

Proses penelitian ini dilakukan secara eksploratif. Peneliti berusaha untuk mendalami fenomena yang terjadi dalam proses pemberian desentralisasi fiskal, khususnya terkait dengan 
pemungutan pajak daerah oleh pemerintah daerah. Setelah fenomena ini dapat digali secara utuh, selanjutnya peneliti melakukan penafsiran mengenai fenomena tersebut untuk selanjutnya memberikan solusi alternatif kebijakan yang terkait dengan pemberian desentralisasi fiskal yang terkait dengan kebijakan perpajakan daerah, khususnya terkait dengan pemungutan pajak daerah oleh pemerintah daerah dalam kaitannya mendukung kebijakan desentralisasi pemerintahan yang lebih baik, yang mewujud dalam pelaksanaan otonomi daerah.

Dari hasil riset ini diharapkan dapat memperkaya bahasan di bidang akuntansi dan perpajakan daerah terkait kemungkinan terjadi perbedaan pola penerimaan di daerah perkotaan (urban area) dengan daerah perdesaan (rural area). Perkembangan ekonomi di kedua daerah tersebut seyogyanya mengalami perbedaan terkait dengan potensi yang berbeda antara daerah perkotaan dan daerah perdesaan. Perubahan pola penerimaan ini akan berkonsekuensi pada terjadinya perbedaan mekanisme optimalisasi penerimaan pajak daerah masing wilayah, urban-rural, dan tentunya hal ini akan berdampak pada proses dan sistem akuntansi penerimaan pajak daerahnya.

\section{TELAAH TEORI PENGEMBANGAN HIPOTESIS}

DAN

Konsep desentralisasi erat kaitannya dengan penyelenggaraan sistem pemerintahan dan pelaksanaan proses pembangunan. Pelaksanaan desentralisasi yang berwujud pada otonomi daerah merupakan suatu gejala yang tidak terhindarkan dan diimplementasikan oleh hampir seluruh negara yang ada di seluruh dunia dengan segala variasinya sesuai dengan kondisi dan karekteristiknya masing-masing. Implementasi kebijakan desentralisasi di suatu negara tidak akan sama dengan pemberlakuan kebijakan yang sama di negara lain. Hal ini kerena tidak ada dua negara yang identik karekteristiknya di dunia ini.

Pemaknaan desentralisasi mengalami perubahan. Desentralisasi tidak lagi hanya dimaknai sebagai penyerahan kekuasaan, kewenangan, dan tanggung jawab dalam suatu pemerintahan, tetapi juga pembagian dari kewenangan dan sumber daya untuk melaksanakan kebijakan publik di dalam masyarakat (Chemaa dan Rondinelli, $2007: 6$ 7). Pemahaman ini membuat konsep desentralisasi dapat dikategorisasikan menjadi empat bentuk, yaitu administratif, politik, fiskal, dan ekonomi.

Untuk menjalankan kewenangan/ kekuasaan yang diberikan ini, tentunya pemerintah daerah memerlukan sumber daya yang cukup. Menurut analisis Nellis (1983) dan Mathur (1983) pada pelaksanaan kewenangan/kekuasaan yang telah didesentralisasikan di Afrika Utara dan Asia, yang penting diperhatikan adalah the importance of financial resources, administrative capacity, and technical support to successful development planning and management at the regional and local level.

Dalam pelaksanaan desentralisasi, kejelasan tanggung jawab dalam aspek keuangan merupakan suatu hal yang sangat penting (Rondinelli, 2000). Jika pemerintah daerah atau organisasi swasta ingin melaksanakan fungsi-fungsi yang telah terdesentralisasikan secara efektif, maka mereka harus memiliki penerimaan yang cukup - baik penghasilan yang diperoleh dari daerah itu sendiri atau merupakan alokasi (transfer) yang berasal dari pemerintah pusat dan, tentunya, kewenangan untuk memutuskan pembelanjaannya.

Di sejumlah negara berkembang, pemerintah-pemerintah daerah berupaya untuk meningkatkan pendapatannya. Beragam langkah ditempuh untuk mewujudkan perolehan penerimaan yang cukup substansial untuk mendukung pelaksanaan otonomi daerah yang diemban oleh pemerintah daerah otonom. Salah satu upaya yang dapat ditempuh oleh pemerintah daerah otonom adalah meningkatkan pendapatan yang berasal dari pajak daerah dengan jalan secara terus menerus mengoptimalkan penerimaan pajak yang telah ada seraya menggali peluang serta potensi pajak daerah baru yang dapat 
diperoleh.

Suatu pemerintah daerah dapat menetapkan dan memungut beragam jenis pajak daerah sesuai dengan potensi yang dimilikinya. Hal ini sangat dimungkinkan jika pemerintah daerah memiliki kemampuan untuk menetapkan sendiri jenis-jenis pajak daerah yang dapat dipungutnya, tanpa ada intervensi dari tingkatan pemerintahan yang lebih tinggi. Agar pemerintah daerah memiliki kemampuan optimal untuk memungut pajak daerah yang ada di daerahnya, perlu kiranya mempertimbangkan pajak-pajak daerah yang memang sesuai untuk dijadikan sumber pendapatan agar tercipta efisiensi dan efektivitas dalam pemungutan pajak daerah.

Keberhasilan implementasi suatu kebijakan tidak terlepas dari bagaimana kebijakan yang telah diputuskan tersebut diimplementasikan. Implementasi disini dapat diartikan bagaimana kebijakan tersebut dijalankan dan dikelola sedemikian rupa sehingga tujuan dari kebijakan yang diambil dapat tercapai. Demikian pula suatu kebijakan desentralisasi perpajakan daerah, demi tercapainya tujuan kebijakan ini, maka ia harus ditunjang dengan administrasi perpajakan daerah yang baik.

Kebijakan yang terkait dengan pemungutan pajak daerah dapat dibagi dalam dua sistem, yaitu open list system dan close list system. Kategorisasi ini dapat dilihat dari bagaimana kita melihat posisi pemerintah daerah dalam kerangka hubungan keuangan pusat - daerah. Davey (1989 : 169) membedakan dua sudut pandang dalam melihat kedudukan ini.

"The first view stresses the role of local government as an expression of the will and identity of local communities. .... The alternative view sees local government essentially as an agency for administering certain local services, an as an appropriate means for recovering costs of services of purely local benefit. ........".

Davey (1989 : 170) berpendapat bahwa posisi pertama dari pemerintah daerah dalam kerangka hubungan keuangan pusat - daerah akan memungkinkan terjadinya pembagian kekuasaan antara pemerintah pusat dengan daerah sehingga pemerintah daerah memiliki keleluasaan yang lebih otonom sebagai untuk memujudkan aspirasi masyarakat setempat. Sedangkan pada posisi kedua, posisi pemerintah daerah lebih bersifat administratif - ekonomis yang menjadi perpanjangan tangan pemerintah pusat untuk memberikan pelayanan publik yang diperlukan oleh masyarakat setempat dengan efektif dan secara ekonomis harus dapat menjalankan tugasnya secara efisien.

Letak perbedaan antara sistem daftar terbuka (open list system) dan sistem daftar tertutup (closed list system) dapat dilihat dari apakah pemerintah daerah memiliki kebebasan untuk menentukan dan menerapkan jenis-jenis pajak daerah yang dapat dipungutnya. Jika pemerintah memiliki kebebasan yang lebih leluasa dalam menentukan dan menerapkan jenis-jenis pajak daerah yang dapat dipungutnya maka sistem perpajakan daerah yang dianut adalah sistem daftar terbuka. Sebaliknya, jika pemerintah kurang atau bahkan tidak memiliki kebebasan dalam menentukan dan menerapkan jenis-jenis pajak daerah yang dapat dipungutnya maka sistem perpajakan daerah yang dianut adalah sistem daftar tertutup. Selain tingkat kebebasan dalam menentukan dan menerapkan jenis-jenis pajak daerah yang dapat dipungutnya, sistem perpajakan daerah akan berimbas dalam jumlah jenis pajak daerah yang akan dipungut, mekanisme pengawasan dari pemerintahan yang lebih tinggi, pengesahan peraturan daerah mengenai pajak daerah, serta kebijakan tarif pajak daerah yang akan diterapkan.

Dalam salah satu studinya Michael Lipton mengemukakan pendapatnya bahwa telah terjadi ketimpangan proses pembangunan antara pembangunan di wilayah pedesaan dengan wilayah perkotaan. Pendapat Lipton ini dikemukakan dalam salah satu bukunya "Why Poor People Stay Poor : Urban bias and World Development" (Lipton, 1977). Menurut Lipton, pemerintah telah melakukan proses pembangunan yang berbeda antara proses pembangunan yang dijalankan di kawasan 
perkotaan (urban area) dengan proses pembangunan yang dilakukan di kawasan pedesaan (rural area). Pendapat ini dikenal dengan tesis bias perkotaan (urban bias thesis).

Lipton (Becker dan Morrison, 1999 : 1721) dalam teori bias perkotaannya berpendapat bahwa kebijakan yang dijalankan lebih cenderung menguntungkan masyarakat kota sebagai produsen dan konsumen dengan mengorbankan masyarakat yang tinggal di kawasan pedesaan. Lipton berpendapat bahwa kebijakan yang dilaksanakan oleh pemerintah terlihat bias terhadap sektor pertanian. Bias ini dapat dilihat dari (1) kebijakan ekonomi makro (terutama kebijakan perdagangan dan kebijakan harga) yang mendistorsi hasil pertanian dengan lebih cenderung meningkatkan nilai tambah produk non pertanian; (2) pemerintah mengalokasikan dana investasi yang lebih besar di kawasan perkotaan dibandingkan dengan dana yang dialokasikan di kawasan pedesaan karena ada anggapan bahwa tingkat pengembalian manfaat (benefit return) atas investasi yang ditanamkan di kawasan pedesaan lebih rendah dibandingkan tingkat pengembalian manfaat jika investasi tersebut dilakukan di kawasan pedesaan; dan (3) perluasan penyediaan fasilitas publik di kawasan perkotaan, terutama di kota-kota besar, dibandingkan dengan penyediaan fasilitas publik di kawasan pedesaan (Becker et. Al., 1994 : 94).

Beragam penelitian dan kajian telah dilakukan dengan topik bahasan pajak daerah. Beberapa penelitian/kajian berikut diantaranya. Lutfi (2011) melakukan studi terkait evolusi perkembangan hubungan fiskal antar tingkat pemerintahan sebagai bagian kebijakan desentralisasi yang difokuskan pada kebijakan perpajakan daerah. Terkait dengan implementasi earmarking policy pada sejumlah penerimaan pajak daerah, terdapat kajian bagaimana prospek implementasi kebijakan ini serta masalah potensial yang menghambat implementasinya (Lutfi, 2013a) dan juga mengkaji bagaimana kaitan earmarking policy dengan akuntabilitas penggunaan penerimaan pajak dilihat dari isi pengaturan pajak daerah di daerah kabupaten dan daerah provinsi
(Lutfi, 2013b). Kajian mengenai pengalihan pemungutan PBB P2 kepada daerah, sebagaimana Amanah UU No. 28/2009 juga pernah dituangkan dalam buku "Devolusi Pajak Bumi dan Bangunan : Tantangan dan Peluang Penguatan Taxing Capacity untuk Mendorong Daya Saing Daerah." Untuk mendukung industri pariwisata, insentif perpajakan daerah untuk mendukung pengembangan industry ini dikaji oleh Rivaldi dan Lutfi (2018). Implementasi kebijakan atas alokasi penerimaan Pajak Rokok yang menggunakan prinsip earmarking policy dikaji oleh Purwanti dan Lutfi (2018). Kajian terhadap organisasi perangkat daerah pemungut pajak daerah dan retribusi daerah dilakukan oleh Nurnaluri, Hasbudin, dan Ratu (2019) dengan evaluasi sistem pengendalian internal pemungutan pajak daerah pada Badan Pengelola Pajak Daerah dan Retribusi Daerah Kota Kendari. Upaya terkait optimalisasi penerimaan pajak daerah, Mulyadi dan Nawangsasi (2020) melakukan kaijian mengenai upaya yang dilakukan oleh Pemerintah Kota Surakarta guna meningkatkan penerimaan pajak daerah sebagai salah satu untuk Pendapatan Asli Daerah.Kajian mengenai analisis implementasi kebijakan pemberian pembebasan Pajak Bumi dan Bangunan Perdesaan dan Perkotaan di Provinsi DKI Jakarta juga pernah dilakukan oleh Larasasti dan Lutfi (2021). Kajian lainnya, terkait dengan pemungutan PBB-P2, mengenai strategi yang dilakukan oleh Pemerintah Provinsi DKI Jakarta dalam rangka pengendalian ruang terbuka hijau melalui PBBP2 juga dilakukan oleh Putra dan Lutfi (2021). Rachman, Anggraeni, dan Wigiyanti (2021) melakukan kajian mengenai pengaruh pemungutan Pajak Parkir dan Pajak Penerangan Jalan terhadap Penerimaan Asli Daerah Kota Bandung untuk periode 20112018.

Perbedaan penelitian/kajian diatas dengan yang dilakukan dalam menyusun artikel ini adalah terletak pada dipergunakannya teori urban bias dalam melihat penerimaan pajak daerah. Perkembangan pembangunan yang 
berdampak pada perubahan kondisi perekonomian antara daerah perkotaan dan perdesaan seyogyanya akan berdampak pada perbedaan pola penerimaan pajak daerah diantara kedua daerah tersebut. Perbedaan ini diakibatkan adanya perbedaan potensi ekonomi yang dihasilkan oleh pembangunan ekonomi. Perbedaan yang dihasilkan ini akan berdampak pada perbedaan pola penerimaan pajak yang dapat membawa konsekuensi perbedaan mekanisme optimalisasi penerimaan pajak daerah masing wilayah, urban-rural, dan tentunya hal ini akan berdampak pada proses dan sistem akuntansi penerimaan pajak daerahnya. Dengan fokus di Daerah Istimewa Yogyakarta dalam kurun waktu 1997-2015, dimana dalam periode ini terimplementasi tiga peraturan perundangundangan yang mengatur pemungutan pajak daerah dengan sistem yang berubah-ubah (open list system dan closed list system) kajian ini dilakukan.

\section{METODE PENELITIAN}

Penelitian dalam rangka penulisan artikel ini dilakukan dengan strategi kualitatif dan diperkaya dengan analisis kuantitatif. Strategi kualitatif digunakan untuk memahami bagaimana pengaturan yang dilakukan oleh pemerintah dalam mengimplementasikan kebijakan desentralisasi pemungutan pajak daerah yang tertuang dalam serangkaian peraturan perundang-undangan sebagai bentuk regulasi yang dibuat oleh pemerintah pemerintah pusat. Untuk memperkaya analisis terhadap regulasi yang dilakukan oleh pemerintah pusat dalam pengatur pemungtan pajak daerah, analisis diperkaya dengan melakukan analisis data deskriptif atas data penerimaan pajak daerah yang diterima oleh pemerintah kabupaten dan pemerintah kota dalam periode 1997 - 2015 dan jenis-jenis penerimaan lainnya yang diperoleh pemerintah kabupaten dan pemerintah kota dalam periode yang sama. Untuk lebih memberikan gambaran yang lebih jelas, secara lebih mendalam, penulisan ini menggambarkan pemungutan pajak daerah oleh pemerintah daerah kabupaten dan pemerintah daerah kota di Daerah Istimewa Yogyakarta pada periode 1997 - 2015 untuk memperoleh gambaran yang lebih jelas atas fenomena yang sama di tingkat lokal.

Proses penelitian ini dilakukan secara eksploratif. Peneliti berusaha untuk mendalami fenomena yang terjadi dalam proses pemberian desentralisasi fiskal, khususnya terkait dengan pemungutan pajak daerah oleh pemerintah daerah. Setelah fenomena ini dapat digali secara utuh, selanjutnya peneliti melakukan penafsiran mengenai fenomena tersebut untuk selanjutnya memberikan solusi alternatif kebijakan yang terkait dengan pemberian desentralisasi fiskal yang terkait dengan kebijakan perpajakan daerah, khususnya terkait dengan pemungutan pajak daerah oleh pemerintah daerah dalam kaitannya mendukung kebijakan desentralisasi pemerintahan yang lebih baik, yang mewujud dalam pelaksanaan otonomi daerah.

\section{HASIL DAN PEMBAHASAN}

Pemberlakuan Undang-Undang Nomor 18 Tahun 1997 tentang Pajak Daerah dan Retribusi Daerah merupakan respon yang diberikan oleh pemerintah pusat dalam mengatasi menjamurnya pungutan pajak daerah, maupun retribusi daerah, yang dipungut oleh pemerintah daerah, termasuk di dalamnya daerah kabupaten dan daerah kota. Salah satu tujuan yang ingin dicapai dengan pemberlakuan ini adalah menghapuskan jneisjenis pajak yang mengganggu (nuisance local tax), yaitu jenis pajak daerah yang memiliki beban terlalu berat dalam aspek administrasi namun menghasilkan penerimaan yang tidak seberapa. Penerapan undang-undang ini juga merupakan titik awal melakukan reformasi perpajakan daerah (local tax reform) dengan tetap memberikan kewenangan pemungutan pajak yang potensial kepada daerah dan sekaligus memberikan kemampuan pemajakan daerah baru kepada daerah (local taxing power).

Pemberlakuan Undang-Undang Nomor 34 Tahun 2000 tentang tentang Perubahan atas Undang-Undang Nomor 18 Tahun 1997 tentang Pajak Daerah dan Retribusi Daerah dapat juga dilihat merupakan respon yang 
diberikan oleh pemerintah pusat untuk memperbesar kemampuan pemajakan daerah (local taxing power) yang dimiliki oleh daerah. Hal ini sangat jelas terlihat dari diberikannya keleluasaan yang besar bagi daerah untuk menetapkan serta memungut jenis pajak daerah baru sepanjang sesuai dengan kriteria.

Pemberlakuan Undang-Undang Nomor 28 Tahun 2009 tentang Pajak Daerah dan Retribusi Daerah merupakan respon yang diberikan oleh pemerintah pusat dalam mengatasi menjamurnya pungutan pajak daerah, maupun retribusi daerah, yang dipungut oleh pemerintah daerah, termasuk di dalamnya daerah kabupaten dan daerah kota. Hal ini merupakan dampak kegagalan pemerintah pusat mengantisipasi pemberlakuan kebijakan sistem daftar terbuka (open list system) dalam pemungutan pajak daerah yang direspon oleh daerah. Pemerintah-pemerintah daerah, termasuk di dalamnya pemerintah daerah kabupaten dan pemerintah daerah kota, seakan-akan berlomba-lomba menentapkan dan mengenakan beragam jenis pajak baru yang disinyalir dapat mendistorsi kegiatan ekonomi di daerah. Dalam pengawasan represif pun, pemerinitah pusat terlihat tidak memiliki kapasitas administratif yang cukup untuk mengelola banyaknya perda-perda pajak daerah baru yang muncul. Ketidakmampuan kapasitas administratif ini ditandai dengan banyaknya rancangan perda maupun perda yang belum dapat dievaluasi tepat pada waktunya.

Dari ketiga periodisasi pemberlakuan peraturan perundang-undangan yang mengatrur tentang desentralisasi perpajakan di Indonesia, pemerintah daerah kabupaten dan pemerintah daerah kota se Daerah Istimewa Yogyakarta memberikan respon yang sangat baik. Respon ini ditunjukkan dengan melakukan pemungutan jenis-jenis pajak daerah yang diperkankan untuk dipungut. Sejumlah daerah kabupaten dan daerah kota melakukan penyesuaian atas jenis pajak daerah yang mereka pungut. Hal ini terjadi karena menurut pertimbangan mereka pemungutan jenis pajak tertentu sulit dilakukan mengingat ketiadaan potensi/basis pemajakan yang tersedia.

Pemerintah daerah kabupaten dan pemerintah daerah kota se Daerah Istimewa Yogyakarta karena memang Pemerintah Kota Yogyakarta berpendapat bahwa apapun sistem pemungutan pajak yang diberlakukan, apakah sistem daftar terbuka (open list system) maupun sistem daftar tertutup (closed list system), tidak terlalu mempengaruhi pemungutan pajak daerah yang dilakukannya sepanjang objek pajak daerah yang ingin dipungut tersedia. Pemerintah Daerah Kota Yogyakarta dan Pemerintah Daerah Kabupaten Sleman perpendapat bahwa sistem daftar terbuka (open list system) maupun sistem daftar tertutup (closed list system) tidak terlalu mempengaruhi pemungutan pajak daerah yang dilakukannya. Hal ini dikarenakan jenis-jenis pajak yang dipungut sangat menguntungkan mereka. Mereka beralasan bahwa jenis-jenis pajak yang dipungut ini menguntungkan daerah perkotaan serta sangat sesuai dengan perkembangan pendapatan regional daerah bruto mereka yang didominasi sektor jasa, serta sektor perdagangan, hotel, dan restoran. Sebaliknya, bagi Pemerintah Daerah Kabupten Bantul, Pemerintah Daerah Kabupten Kulon Progo, serta Pemerintah Daerah Kabupten Gunungkidul memiliki alasan yang berbeda untuk memiliki pendapat yang sama bahwa sistem daftar terbuka (open list system) maupun sistem daftar tertutup (closed list system) tidak terlalu mempengaruhi pemungutan pajak daerah yang dilakukannya. Mereka beralasan bahwa hal ini dikarenakan jenis-jenis pajak yang dipungut belum cukup menguntungkan mereka. Mereka beralasan bahwa jenis-jenis pajak yang dipungut pada kedua sistem tersebut lebih menguntungkan daerah perkotaan serta sangat sesuai dengan perkembangan pendapatan regional daerah bruto di daerah perkotaan yang didominasi sektor jasa, serta sektor perdagangan, hotel, dan restoran.

Temuan di pemerintah daerah kabupaten dan pemerintah daerah kota se Daerah Istimewa Yogyakarta ini mengokohkan bahwa adanya urban bias dapat memberikan andil dalam menciptakan ketimpangan penerimaan 
pendapatan asli daerah dari komponen pajak daerah yang dipungut oleh pemerintah daerah kabupaten dan pemerintah daerah kota. Selain urban bias, temuan lainnya adalah bahwa apapun sistem pemungutan pajak daerahnya, apakah sistem daftar terbuka (open list system) maupun sistem daftar tertutup (closed list system), pemerintah daerah akan diuntungkan apabila jenis-jennis pajak daerah yang dipungut sesuai dengan potensi perekonomian daerah yang dapat diindikasikan dari komposisi sektor yang dominan dalam perkembangan pendapatan regional daerah bruto.

Pada saat diberlakukannya kebijakan sistem daftar terbuka (open list system), sebenarnya bisa saja pemerintah daerah kabupaten dan pemerintah daerah kota se Daerah Istimewa Yogyakarta memungut jenis pajak baru, selain yang secara tegas telah dicantumkan dalam undang-undang. Namun demikian hal ini tidak dilakukan oleh pemerintah daerah. Hal ini disebabkan karena baik pihak eksekutif maupun legislatif daerah kabupaten dan daerah kota se Daerah Istimewa Yogyakarta bersikap hati-hati dalam mengambil keputusan seraya memperhatikan apakah masih ada potensi pajak baru yang dapat dipungut. mereka semua memandang bahwa tidak ada lagi potensi pajak baru yang dapat dikenakan, sehingga mereka tidak mempergunakan haknya untuk memungut jenis pajak daerah baru pada saat diberlakukannya kebijakan sistem daftar terbuka (open list system).

Dari serangkaian pembahasan mengenai respon yang diberikan oleh pemerintah daerah kabupaten dan pemerintah daerah kota di Daerah Istimewa Yogyakarta, dapat dipastikan bahwa respon yang diberikan ini telah sesuai dengan kelaziman yang ada. Respon yang diberikan pemerintah daerah kabupaten dan pemerintah daerah kota di Daerah Istimewa Yogyakarta ini pun sejalan dengan pandangan yang dikemukakan oleh para teoritisi, seperti Davey (1993), Tanzi (1995), serta Bird (2000a dan 2010), sebagaimana tertulis dalam literaturliteraturnya. Lazimnya respon yang diberikan oleh pemerintah-pemerintah daerah dibelahan dunia lainnya adalah mengikuti apa yang telah digariskan oleh pemeriintah pusat dalam serangkaian peraturan perundangundangannya.

Seperti telah disebutkan diatas, komponen PAD terdiri dari sejumlah komponen. Besaran penerimaan masing-masing komponen PAD akan berbeda perolehannya untuk daerah kabupaten dan daerah kota. Perbedaan ini akan dapat dilihat baik secara akumulatif, dilihat untuk seluruh daerah kabupaten dan daerah kota se Indonesia, maupun dilihat secara ratarata, dilihat secara rata-rata untuk masingmasing daerah kabupaten dan daerah kota di Indonesia.

Apabila dirata-ratakan per tahunnya, maka rata-rata penerimaan komponen selain pajak daerah dan retribusi daerah berada diatas rata-rata perolehan komponen pajak daerah serta rata-rata penerimaan komponen retribusi daerah di daerah kabupaten di Indonesia. Apabila dirata-ratakan per tahunnya, maka rata-rata penerimaan komponen pajak daerah berada diatas rata-rata perolehan komponen retribusi daerah serta rata-rata penerimaan komponen selain pajak daerah dan retribusi daerah di setiap daerah kota di Indonesia.

Hasil analisis data mempertunjukkan bahwa hasil pendapatan per komponen yang tercakup dalalm konsep pendapatan asli daerah akan berbeda hasilnya di daerah kabupaten dan daerah kota. Penerimaan PAD yang berasal dari komponen pajak daerah di daerah kabupaten berada di posisi kedua. Sedangkan penerimaan dari komponen yang sama untuk daerah kota berada di posisi pertama. Dilihat dari perolehan akumulatif, baik untuk daerah kabupaten dan daerah kota se Indonesia, maupun data rata-rata, untuk daerah kabupaten dan daerah kota di, terlihat bahwa perolehan pendapatan komponen pajak daerah di daerah kota lebih besar dibandingkan dengan hasilnya di daerah kabupaten. Apabila dirinci per tahun, akan jelas terlihat bahwa sejak dilakukan pemungutan PBB P2 dan BPHTB oleh pemerintah daerah kabupaten dan daerah kota sebagai pajak daerah, perolehan penerimaan pajak daerah meningkat lebih pesat baik di daerah kota maupun daerah kota. 
Fenomena ini sangatlah wajar. Kewajaran ini timbul karena objek pajak daerah, local tax base, baik dari PBB P2 maupun BPHTB dimiliki oleh daerah kabupaten maupun daerah kota. Keberadaan basis pemajakan daerah ini mendukung peningkatan penerimaan pajak daerah baik di daerah kabupaten dan daerah kota. Namun demikian peningkatan perolehan pajak di daerah kabupaten belum dapat mengejar besaran perolehan pajak daerah di daerah kota.

Hasil analisis data mempertunjukkan bahwa prosentase kontribusi per komponen yang tercakup dalalm konsep pendapatan asli daerah akan berbeda hasilnya di daerah kabupaten dan daerah kota. Prosentase kontribusi penerimaan PAD yang berasal dari komponen pajak daerah terlihat cukup dominan baik di daerah kabupaten maupun daerah kota. Dilihat dari prosentase kontribusi perolehan secara akumulatif, baik untuk daerah kabupaten dan daerah kota se Indonesia, maupun data rata-rata prosentase kontribusi, untuk daerah kabupaten dan daerah kota di, terlihat bahwa prosentase kontribusi perolehan pendapatan komponen pajak daerah di daerah kota lebih besar dibandingkan dengan hasilnya di daerah kabupaten. Apabila dirinci pertahun, fenomena yang sama juga akan terlihat bahwa sejak dilakukan pemungutan PBB P2 dan BPHTB oleh pemerintah daerah kabupaten dan daerah kota sebagai pajak daerah, perolehan penerimaan pajak daerah meningkat lebih pesat baik di daerah kota maupun daerah kota. Hal lain yang juga diperoleh dari hasil analisis adalah bahwa prosentase kontribusi penerimaan komponen pajak daerah terhadap total penerimaan PAD di daerah kota jauh lebih besar dibanding hal yang sama di daerah kabupaten. Hal ini dapat menjadi indikasi bahwa basis pajak daerah di daerah kota jauh lebih banyak dan variatif dibandingkan di daerah kabupaten.

Pemungutan pajak daerah tidak terlepas dari potensi ekonomi yang dimiliki oleh daerah. Potensi ekonomi daerah yang telah tergali, terealisasi dan mewujud menjadi suatu yeng lebih konkret dan memiliki nilai ekonomis dapat dikenakan pajak daerah. Pengenaan pajak daerah ini tidak terlepas dari basis pemajakan yang telah diatur oleh peraturan perundang-undangan yang mengatur tentang pajak daerah.

Serangkaian kebijakan perpajakan daerah yang telah diimplementasikan selama ini, baik dalam sistem daftar terbuka maupun daftar tertutup, terlihat cukup menguntungkan daerah kota, sebagai bentuk daerah perkotaan (urban area). Keuntungan yang diperoleh kawasan perkotaan ini disebabkan karena basis pengenaan pajak daerah merupakan aktivitasaktivitas perekonomian yang berkembang di perkotaan.

Jika diperhatikan dari dengan seksama keuntungan yang diperoleh daerah perkotaan dapat ditelusuri dari jenis dan objek yang ditetapkan untuk dikenakan pajak daerah dalam peraturan perundabng-undangan. Basis pemajakan dari aktivitas perhotelan, restoran, hiburan, dan reklame, merupakan serangkaian contoh aktivitas ekonomi yang lebih dominan terjadi di kawasan perkotaan dibandingkan terjadinya aktivitas ini di kawasan perdesaan.

Hal yang tidak kalah pentingnya, adalah ketersediaan sumber daya dalam rangka implementasi kebijakan desentraliasi. Tidak dapat dipungkiri, kemampuan pemerintah kota dalam hal ketersediaan sumber daya manusia (personel), perlengkapan dan pembiayaan, biasanya dikenal dengan konsep 3P, juga menentukan keberhasilan untuk merealisasikan pendapatan pajak daerah dengan basis pemajakan yang telah menguntungkannya juga menjadi penting. Walaupun hal ini perlu dibuktikan lebih seksama, karena kabupaten sebagai representasi kawasan pedesaan bukan tidak mungkin memiliki hal sama dengan daerah perkotaan, tetapi tetapi basis pemajakan yang tersedia ditunjang dengan ketersediaan 3P cukup merupakan kombinasi yang sangat baik.

Pemerintah Republik Indonesia telah melakukan Desentralisasi Perpajakan dengan memberikan kewenangan kepada daerah otonom untuk memungut pajak daerah berdasarkan sejumlah peraturan perundangundangan yang diberlakukan secara silih 
berganti. Peraturan perundang-undangan ini antara lain berisi jenis-jenis pajak daerah yang dapat dipungut oleh daerah otonom, baik untuk daerah provinsi maupun daerah kabupaten/kota. Selain mengenai jenis pajak daerah yang dapat dipungut oleh daerah otonom, hal penting lainnya yang diatur dalam peraturan perundang-undangan ini adalah apakah daerah otonom dimungkinkan untuk memungut jenis pajak daerah selain jenis pajak daerah yang sudah secara tegas ditetapkan dalam peraturan perundang-undangan tersebut. Apabila dalam peraturan perundangundangan secara tegas ditetapkan bahwa daerah otonom hanya bisa memungut jenis pajak daerah yang telah tercantum, maka sistem perpajakan daerah yang diberlakukan berdasarkan peraturan perundang-undangan tersebut adalah sistem tertutup (close list). Sebaliknya apabila apabila dalam peraturan perundang-undangan ditetapkan bahwa daerah otonom dapat memungut jenis pajak daerah lainnya selain jenis pajak daerah yang telah tercantum, maka sistem perpajakan daerah yang diberlakukan berdasarkan peraturan perundang-undangan tersebut adalah sistem terbuka (open list).

Dari data diatas terlihat bahwa peneraparan sistem daftar tertutup (closed list system) maupun sistem daftar terbuka (open list system) dalam pemungutan pajak daerah baik oleh Pemerintah Daerah Kabupaten maupun Pemerintah Daerah Kota belum dapat mengurangi perbedaan perolehan pajak daerah di Daerah Kabupaten maupun Daerah Kota. Perbedaan ini disebabkan perbedaan keberadaan objek pajak daerah diantara kedua daerah tersebut. Objek pajak daerah yang selama ini dipungut baik pada masa peneraparan sistem daftar tertutup (closed list system) maupun sistem daftar terbuka (open list system) terlihat lebih menguntungkan daerah perkotaan.

Daerah perkotaan dengan perkembangan dinamika di sektor jasa-jasa serta sektor perdagangan, hotel dan restoran, sangat diuntungkan objek pajak daerah yang telah diterakapkan selama kurun waktu 1997 - 2015. Kontribusi sektor jasa-jasa serta sektor perdagangan, hotel dan restoran sebagai kontributor utama pembentuk Produk Domestik Regional Bruto daerah perkotaan memiliki korelasi yang positif dengan objek pajak daerah yang selama ini pungut oleh Pemerintah Daerah Perkotaan.

Daerah perdesaan, dimana merupakan ciri dari Daerah Kabupaten, tidak terlalu diuntungkan dengan jenis-jenis pajak daerah dipungut selama kurun waktu 1997 - 2015. Kontribusi sektor pertanian yang menjadi kontributor penting pembentuk Produk Domestik Regional Bruto daerah perkotaan belum memiliki korelasi yang positif yang cukup dengan objek pajak daerah yang selama ini pungut oleh Pemerintah Daerah Kabupaten.

Perbedaan yang cukup signifikan terjadi apabila Daerah Kabupaten memiliki potensi pariwisata dan telah mengalami proses urbanisasi. Proses urbanisasi ini tidak selalu perlu melanda seluruh wilayah suatu Daerah Kabupaten, karena biasanya daerah yang mengalami proses urbanisasi adalah bagian Daerah Kabupaten yang berbatasan dengan Daerah Kota. Proses urbanisasi ini dapat diartikan sebagai proses pengkotaan, menjadi kota, dimana sektor-sektor ekonomi perkotaan berkembang dengan pesat di daerah yang mengalami urbanisasi akibat interaksi yang sangat erat dengan Daerah Kota.

Perbedaan rata-rata penerimaan pajak daerah baik pada daerah kabupaten maupun daerah kota, pada masa pemberlakuan UU No. 18/1997, UU No. 34/2000, maupun pada masa pemberlakuan UU No. 28/2009 merupakan hal yang wajar terjadi. Hal ini dapat terjadi karena pada saat pemberlakuan UU No. 18/1997, UU No. 34/2000, maupun pada masa pemberlakuan UU No. 28/2009 pemerintah pusat selalu melakukan perubahan jenis pajak daerah yang dapat dipungut oleh daerah kabupaten dan daerah kota. Perubahan ini tidak membeda-bedakan apakah darah itu bertipe urban (daerah kota) maupun daerah rural (daerah kabupaten). Kedua tipe daerah ini diperlakukan sama dan dapat memungut jenis pajak daerah yang sama.

Pemberian kewenangan pemajakan daerah yang cukup fenomenal adalah 
melakukan pendaerahan pemungutan Pajak Bumi dan Bangunan Perdesaan dan Perkotaan serta BPHTB kepada daerah kabupaten dan daerah kota. Pengalihan kedua jenis pajak tersebut dari pajak pusat yang hasilnya dibagi hasilkan penerimaannya menjadi sepenuhnya menjadi pajak daerah merupakan hal yang sangat membantu meningkatkan penerimaan pajak daerah. Peningkatan ini sangat dimungkinkan karena kedua objek pajak tersebut ini ada di setiap daerah, walaupun dalam batas-batas tertentu terjadi variasi nilai jual objek pajak yang menjadi dasar pengenaannya.

Walaupun daerah kabupaten dan daerah kota memperoleh kewenangan pemungutan jenis pajak daerah yang sama, tetap saja kebijakan ini belum dapat mengurangi ketimpangan penerimaan pandapatan asli daerah dari komponen pajak daerah yang dipungut oleh pemerintah daerah kabupaten dan pemerintah daerah kota. Ketimpangan ini lebih banyak dipengaruhi oleh potensi pajak daerah yang berbeda-beda yang dimiliki oleh daerah kabupaten dan daerah kota. Meskipun dapat memungut jenis pajak daerah yang sama, tetap saja keberadaan basis pemajakan yang bersifat urban lebih menguntungkan daerah kota. Keberadaan basis pemajakan yang berbeda ini akan tetap menyebabkan ketimpangan penerimaan pandapatan asli daerah dari komponen pajak daerah yang dipungut oleh pemerintah daerah kabupaten dan pemerintah daerah kota tetap saja terjadi.

Untuk masa datang kiranya perlu kembali dilakukan penguatan kemampuan perpajakan daerah untuk daerah kabupaten dan daerah perkotaan. Penguatan ini dapat meniru langkah yang dilakukan sebelumnya dengan mendaerahkan jenis pajak tertentu yang objek pajaknya ada di daerah, baik kabupaten maupun kota. Pajak Penghasilan (PPh) Pasal 21 dan Pasal 25/29 Orang Pribadi yang pada saat sekarang dibagihasilkan penerimaannya kepada daerah kabupaten dan daerah kota daerah dapat dipertimbangkan untuk dialihkan menjadi pajak daerah. Pengaliah pajak ini menjadi pajak daerah bisa dilakukan dalam dalam bentuk opsen atau piggy back, dimana pemerintah daerah dapat memiliki kemampuan serta diberikan kewenangan untk mengenakan opsen sampai dengan batas tertentu. Kebijakan ini diharapkan dapat mengurangi dampak dari terjadinya bias perkotaan aas objek-objek ajak daerah saat ini. Kebijakan ini sekaligus diharapkan dapat menghilangkan upaya Daerah untuk menggali sumber-sumber PAD yang memiliki dampak distortif terhadap kegiatan ekonomi.

Penerapan sistem pemungutan pajak daerah yang berbeda oleh Pemerintah Republik Indonesia sebagaimana tertuang dalam peraturan perundang-undangan yang ada, yaitu menerapkan sistem daftar tertutup pada periode pemberlakuan Undang-Undang Nomor 18 Tahun 1997 tentang Pajak Daerah dan Retribusi Daerah dan Undang-Undang Nomor 28 Tahun 2009 tentang Pajak Daerah dan Retribusi Daerah serta pemberlakauan sistem daftar terbuka pada pemberlakuan Undang-Undang Nomor 34 Tahun 2000 tentang Perubahan atas Undang-Undang Nomor 18 Tahun 1997 tentang Pajak Daerah dan Retribusi Daerah memberikan corak yang berbeda dalam pemungutan pajak daerah. Corak yang berbeda ini terutama dalam upaya yang dapat ditempuh baik oleh pemerintah daerah maupun pemerintah pusat untuk mengoptimalkan penerimaan daerah dari komponen pajak daerah. Corak yang berbeda ini dimungkinkan muncul akibat perbedaan karakteristik utama yang melekat pada kedua sistem pemungutan pajak daerah dimaksud.

Dalam setiap periode pemberlakuan peraturan perundang-undangan yang mengatur pemungutan pajak daerah, yang didalamnya mencerminkan sistem pemungutan pajak daerah yang diberlakukan, baik pemerintah pusat maupun pemerintah daerah telah berupaya untuk mengoptimalkan penerimaan pajak daerah walaupun memiliki berbagai keterbatasan akibat dari implementasi system pemungutan pajak daerah yang berlaku. Setiap pemberlakuan system pemungutan pajak daerah berimplikasi dari berbedanya upaya yang dapat ditempuh oleh pemerintah, baik pusat maupun daerah, untuk mengoptimalkan penerimaan pajak daerah. 
Keberadaan objek pajak daerah di daerah yang memiliki kewenangan memungut pajak daerah merupakan prasyarat mutlak keberhasilan optimalisasi pemungutan pajak daerah untuk meningkatkan penerimaan daerah yang bersumber pada pajak daerah. Sistem pemungutan apapun yang diberlakukan serta upaya optimalisasi apapun yang dilakukan, baik oleh pemerintah pusat maupun daerah, tidak akan berhasil dengan baik tanpa keberadaan objek pajak daerah di daerah yang memiliki kewenangan unutuk memungutnya.

\section{SIMPULAN}

Dari temuan dan pembahasan dapat disimpulkan beberapa hal. Pertama, implementasi kebijakan desentralisasi perpajakan daerah pada pemerintah kabupaten dan pemerintah kota di Republik Indonesia dilakukan dengan memberikan kemampuan kepada daerah otonom, termasuk didalamnya pemerintah daerah kabupaten dan daerah kota, untuk memiliki kemampuan melakukan upaya pemajakan dengan memberikan kemampuan untuk mengenakan pajak daerah (local taxing power). Kedua, sistem daftar terbuka atau sistem daftar tertutup dalam pemungutan pajak daerah oleh pemerintah daerah kabupaten/kota belum dapat mengurangi ketimpangan penerimaan pandapatan asli daerah dari komponen pajak daerah yang dipungut oleh pemerintah daerah kabupaten dan pemerintah daerah kota di Daerah Istimewa Yogyakarta. Ketiga, kebijakan open list system dan closed list system dalam pemungutan pajak daerah oleh pemerintahan daerah kabupaten/kota di Indonesia belum dapat mengurangi ketimpangan penerimaan pandapatan asli daerah dari komponen pajak daerah yang dipungut oleh pemerintah kabupaten dan pemerintah daerah kota karena jenis pajak yang dipungut belum memperhatikan potensi ekonomi yang berkembang daerah.

Berdasarkan temuan dan pembahasan tersebut dapat disarankankan sejumlah hal. Pertama, kebijakan desentralisasi perpajakan daerah ini seyogyanya secara terus menerus disempurnakan guna mendukung kebijakan desntralisasi pemerintahan kepada daerah otonom. Kebijakan desentralisasi perpajakan daerah yang kondusif kiranya akan meningkatkan perolehan penerimaaan komponen pajak daerah, sebagai salah satu komponen Pendapatan Asli Daerah. Kedua, untuk mengurangi ketimpangan penerimaan PAD, perlu kiranya pemerintah pusat kembali memberikan kemampuan pemajakan kepada daerah (local taxing power) atas basis-basis pajak daerah yang ada di daerah. Basis-basis pajak daerah ini yang akan diserahkan ini kiranya perlu dipastikan dimiliki oleh setiap daerah kabupaten dan pemerintah daerah kota. Ketiga, pemerintah Indonesia hendaknya memperhatikan potensi ekonomi yang berkembang di daerah dalam memberikan basis pemajakan (tax base) baru dalam rangka pelaksanaan desentralisasi perpajakan guna mengurangi ketimpangan penerimaan pandapatan asli daerah dari komponen pajak daerah yang dipungut oleh pemerintah kabupaten dan pemerintah daerah kota.

\section{REFERENSI}

Larasati, Dewi dan Achmad Lutfi. 2021. "Analisis Implementasi Kebijakan Pemberian Pembebasan Pajak Bumi dan Bangunan Perdesaan dan Perkotaan di Provinsi DKI Jakarta." Syntax Literate: Jurnal Ilmiah Indonesia, Volume 6, Nomor 2, Februari 2021, Syntax Corporation Indonesia.

Lutfi, Achmad. 2011. "Evolution of Intergovernmental Fiscal Relations between Central and Local Government in the Implementation of Decentralization Policy (Study of Local Taxation Policies in Indonesia)", disajikan pada The $2^{\text {nd }}$ International Conference Asian Association for Public Administration (AAPA 2011) "Enhancing Public Trust in Changing Asian Societies" held by The Department of Administrative Sciences, Faculty of Social and Political Sciences, University of Indonesia, 7 - 9 February, 2010, Depok, West Java, Indonesia. 
2013a. "Local Earmarking Tax in Indonesia : Prospect and Potential Problems", disajikan pada The $3^{\text {rd }}$ International Conference on Public Organization (IConPO, 2013) “The New Phenomena on Public Administration in Asian Countries" held by Magister Science in Public Administration, UNR Postgraduate College, Ngurah Rai University, 21 February, 2013, Bali, Indonesia.

2013b. "Pemungutan Pajak Daerah Berkonsep Earmarking Tax dan Akuntabilitasnya (Studi Terhadap Adopsi Konsep Earmarking Tax dalam Peraturan Daerah tentang Pajak Daerah di Indonesia)", disajikan dalam Konferensi Tahunan Indonesian Association for Public Administration (IAPA Annual Conference) 2013, Tanggal 22 - 24 Oktober 2013 di Depok, Jawa Barat, Indonesia, diselenggarakan oleh Departemen Ilmu Administrasi, Fakultas Ilmu Sosial dan Ilmu Politik, Universitas Indonesia.

. 2013c. Devolusi Pajak Bumi dan Bangunan : Tantangan dan Peluang Penguatan Taxing Capacity untuk Mendorong Daya Saing Daerah. Jakarta : Penerbit Universitas Indonesia (UIPress). ISBN : 978 - 979 - 456 - 541 - 4.

Mulyadi, M., \& Nawangsasi, E. (2020). Upaya Mengoptimalkan Pemungutan Pajak Daerah Untuk Meningkatkan Pendapatan Asli Daerah Di Kota Surakarta. ADVANCE, 7(2), 86-100.

Nurnaluri, S., Hasbuddin, H., \& Ratu, W. O. M. (2019). Evaluasi Sistem Pengendalian Internal Pemungutan Pajak Daerah Pada Badan Pengelola Pajak Dan Retribusi Daerah Kota Kendari. JURNAL AKUNTANSI DAN KEUANGAN, 4(2).

Purwanti, Nurul Dyah Ayu dan Achmad Lutfi. 2018. "Evaluation of Revenue Allocation
Policy for Cigarette Tax" disajikan dalam The $2^{\text {nd }}$ International Conference on Administrative Science, Policy, and Governance Studies (The $2^{\text {nd }}$ ICAS PGS), tanggal 30 - 31 Oktober 2018 di Jakarta Selatan, DKI Jakarta, Indonesia, diselenggarakan oleh Fakultas Ilmu Administrasi, Universitas Indonesia.

Putra, Edwinsyah dan Achmad Lutfi. 2021. "Strategi Pemerintah Provinsi DKI Jakarta dalam Rangka Pengendalian Ruang Terbuka Hijau melalui PBBP2." Syntax Literate: Jurnal Ilmiah Indonesia, Volume 6, Nomor 2, Februari 2021, Syntax Corporation Indonesia.

Rachman, D., Anggraeni, I., \& Wigiyanti, N. (2021). Pengaruh pemungutan pajak parkir dan pajak penerangan jalan terhadap penerimaan pendapatan asli daerah kota bandung periode 20112018. AKURAT| Jurnal Ilmiah Akuntansi FE UNIBBA, 12(1), 33-47.

Rivaldi, Rivaldi dan Achmad Lutfi. 2018. "Alternative Design to the Local Tax Incentive Policy in Sekotong Tourist Site, The District of West Lombok" disajikan dalam The $2^{\text {nd }}$ International Conference on Administrative Science, Policy, and Governance Studies (The 2nd ICAS PGS), tanggal 30 - 31 Oktober 2018 di Jakarta Selatan, DKI Jakarta, Indonesia, diselenggarakan oleh Fakultas Ilmu Administrasi, Universitas Indonesia. 